\title{
Solvothermal syntheses, crystal structures, optical and thermal properties of new selenidogermanate and polyselenidogermanate
}

\author{
SHUZHEN LIU, PEIPEI SUN, JINGYU HAN, YUN LIU, YALI SHEN, CHUNYING TANG, \\ HUI SUN and DINGXIAN JIA* \\ College of Chemistry, Chemical Engineering and Materials Science, Soochow University, Suzhou 215123, \\ People's Republic of China. \\ Email: jiadingxian@suda.edu.cn
}

MS received 14 September 2016; revised 5 December 2016; accepted 22 December 2016

\begin{abstract}
New selenidogermanate salts $\left[\mathrm{NH}_{4}\right]_{2}\left[\mathrm{H}_{2} \mathrm{~N}\left(\mathrm{CH}_{3}\right)_{2}\right]_{2} \mathrm{Ge}_{2} \mathrm{Se}_{6}(\mathbf{1})$ and $\left[\mathrm{Ni}(\mathrm{dien})_{2}\right]_{2} \mathrm{Ge}_{2} \mathrm{Se}_{5}\left(\mathrm{Se}_{2}\right)(\mathbf{2})$ (dien $=$ diethylenetriamine), and a selenidogermanate complex $\left[\{\mathrm{Ni}(\mathrm{tepa})\}_{2}\left(\mu-\mathrm{Ge}_{2} \mathrm{Se}_{6}\right)\right]$ (3) (tepa $=$ tetraethylenepentamine) were prepared by solvothermal reactions. Compounds $\mathbf{1}$ and $\mathbf{2}$ consist of discrete $\left[\mathrm{Ge}_{2} \mathrm{Se}_{6}\right]^{4-}$ and $\left[\mathrm{Ge}_{2} \mathrm{Se}_{7}\right]^{4-}$ anions, and $\mathrm{NH}_{4}^{+},\left[\mathrm{H}_{2} \mathrm{~N}\left(\mathrm{CH}_{3}\right)_{2}\right]^{+}$and $\left[\mathrm{Ni}(\mathrm{dien})_{2}\right]^{2+}$ counter cations, respectively. The $\left[\mathrm{Ge}_{2} \mathrm{Se}_{6}\right]^{4-}$ anion is constructed by two tetrahedral $\mathrm{GeSe}_{4}$ building units via edge-sharing. In 2 , two tetrahedral $\mathrm{GeSe}_{4}$ units are linked by a corner and a Se-Se bond to form a polyselenidogermanate anion $\left[\mathrm{Ge}_{2} \mathrm{Se}_{7}\right]^{4-}$ containing a five-membered ring $\mathrm{Ge}_{2} \mathrm{Se}_{3}$. The dimeric $\left[\mathrm{Ge}_{2} \mathrm{Se}_{6}\right]^{4-}$ anion acts as a bridging ligand via the trans terminal Se atoms to link two [Ni(tepa) $]^{2+}$ cations, resulting in neutral complex $\mathbf{3}$. The $\mathrm{Ni}^{2+}$ ion in $\mathbf{2}$ is coordinated by two tridentate dien ligands, while it is coordinated by a pentadentate tepa ligand and a selenidogermanate anion in 3 . The different coordination environments of $\mathrm{Ni}^{2+}$ ions indicate the influence of the denticity of ethylene polyamines on the formation of selenidogermanates in the presence of transition metal ions. The compounds 1-3 exhibit optical band gaps between 2.06 and $2.35 \mathrm{eV}$.
\end{abstract}

Keywords. Selenidogermanates; nickel; solvothermal syntheses; crystal structures; optical properties

\section{Introduction}

The design and syntheses of new crystalline inorganicorganic hybrid chalcogenide materials have become an increasingly active area due to their structural diversity and potential applications in the fields such as photocatalysis, fast ion conductivity, ion exchange, magnetism and thermoelectrics. ${ }^{1-6}$ During the last decade, a great many of chalcogenidogermanates have been prepared by solvothermal method, which has proven to be a fruitful route to chalcogenide materials. ${ }^{7-11}$ From a structural point of view, the cations used to compensate the negative charges of the chalcogenidogermanate anions can be classified as metal cations, ${ }^{12-18}$ and organic quaternary ammonium or protonated amine cations. ${ }^{19-29}$ Recently, a number of chalcogenidogermanates were synthesized in the presence of transition metal (TM) or lanthanide $(\mathrm{Ln})$ ions in polyamine solutions, ${ }^{30-41}$ giving $\left[\mathrm{Mn}(\mathrm{en})_{3}\right] \mathrm{GeSb}_{2} \mathrm{~S}_{6}$ (en = ethylenediamine), ${ }^{32}$ $\left.\left[\mathrm{Co}(\text { dien })_{2}\right]_{2} \mathrm{GeSb}_{4} \mathrm{~S}_{10},{ }^{32}[\mathrm{Ni} \text { (dien) }]_{2}\right]_{3}\left[\mathrm{Ge}_{3} \mathrm{Sb}_{8} \mathrm{~S}_{21}\right] \cdot 0.5 \mathrm{H}_{2} \mathrm{O}$ $($ dien $=$ diethylenetriamine $),{ }^{33}\left[\mathrm{Ni}_{2}(\text { teta })_{3}\right] \mathrm{Ge}_{4} \mathrm{~S}_{10}$. $\mathrm{H}_{2} \mathrm{O}$ (teta $=$ triethylenetetramine), ${ }^{34}\left\{\left[\mathrm{Mn}(\mathrm{en})_{3}\right]_{2}\right.$

*For correspondence
$\left.\left(\mathrm{Ge}_{5} \mathrm{Te}_{10}\right)\right\}_{\mathrm{n}},{ }^{35}$ and $\left[\{\mathrm{Ln}(\text { tepa })(\mu-\mathrm{OH})\}_{2}\left(\mu-\mathrm{Ge}_{2} \mathrm{Se}_{8}\right)\right]_{\mathrm{n}}$ $(\mathrm{Ln}=\mathrm{Eu}, \mathrm{Gd}, \mathrm{Dy})($ tepa $=$ tetraethylenepentamine $),{ }^{40}$ for example. The ethylene polyamines play an important role on the formation of thiogermanates in the presence of transition metal ion. The ethylene polyamine serves not only as reaction medium, but also as chela ting ligand to the TM centers to form a complex cation. In en and dien solutions, the $\mathrm{TM}^{2+}$ complex cations were employed to prepare discrete chalcogenidogermanates in superheated polyamines. Because, the coordination sites of $\mathrm{TM}^{2+}$ ions are prone to be saturated by three bidentate en or two tridentate dien ligands. The incorporation of TM to chalcogenidogermanates is well produced by choosing the tetradentate or pentadentate amino ligands, such as 1,4,8,11-tetraazacyclotetradecane (cyclam) and tetraethylenepentamine (tepa). The $\mathrm{TM}^{2+}$ ion is coordinated by the amino ligand and leaves one or more potential binding site(s) which is fully occupied by a terminal S or Se atom of the chalcogenidogermanate anion. As a result, TM-chalcogenidogermanate complexes [\{Mn(cyclam $\left.)\}_{2}\left(\mu-\mathrm{Ge}_{2} \mathrm{Se}_{7}\right)\right]$. $\mathrm{CH}_{3} \mathrm{OH} \cdot 1.5 \mathrm{H}_{2} \mathrm{O}$, [ $\left.\{\mathrm{TM}(\text { tepa })\}_{2}\left(\mu-\mathrm{Ge}_{2} \mathrm{~S}_{6}\right)\right](\mathrm{M}=\mathrm{Co}$, $\mathrm{Ni}, \mathrm{Mn})$, and $\left[\{\mathrm{M}(\text { tepa })\}_{2}\left(\mu-\mathrm{Ge}_{2} \mathrm{Se}_{6}\right)\right](\mathrm{TM}=\mathrm{Mn}, \mathrm{Fe})$ were obtained. ${ }^{42-45}$ 
Now, reaction of $\mathrm{GeO}_{2}$ and $\mathrm{Se}$ was investigated under different solvothermal conditions. A new selenidogermanate with mixed cations, $\left[\mathrm{NH}_{4}\right]_{2}\left[\mathrm{H}_{2} \mathrm{~N}\right.$ $\left.\left(\mathrm{CH}_{3}\right)_{2}\right]_{2} \mathrm{Ge}_{2} \mathrm{Se}_{6}(\mathbf{1})$ was prepared by the reaction with $\mathrm{NH}_{4} \mathrm{Cl}$ in $\left(\mathrm{CH}_{3}\right)_{2} \mathrm{NH}$ solution. The reaction with $\mathrm{NiCl}_{2}$ in methanol solution of dien produced a polyselenidogermanate $\left[\mathrm{Ni}(\mathrm{dien})_{2}\right]_{2} \mathrm{Ge}_{2} \mathrm{Se}_{5}\left(\mathrm{Se}_{2}\right)$ (2) with $\mathrm{Ni}$ (II) complex cation for the first time. The same reaction with tepa instead of dien afforded a Ni(II) complex with a selenidogermanate ligand $\left[\{\mathrm{Ni}(\text { tepa })\}_{2}\left(\mu-\mathrm{Ge}_{2}\right.\right.$ $\left.\mathrm{Se}_{6}\right)$ ] (3). Herein, we present the syntheses, crystal structures, and characterization of optical and thermal properties of compounds $\mathbf{1}-\mathbf{3}$.

\section{Experimental}

\subsection{Synthesis}

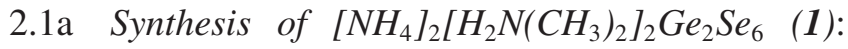
$\mathrm{GeO}_{2}$ (52 mg, $\left.0.5 \mathrm{mmol}\right), \mathrm{Se}(156 \mathrm{mg}, 2 \mathrm{mmol}), \mathrm{NH}_{4} \mathrm{Cl}$ $(53 \mathrm{mg}, 1.0 \mathrm{mmol})$, were dispersed in $\left(\mathrm{CH}_{3}\right)_{2} \mathrm{NH}(3.0 \mathrm{~mL})$ and $\mathrm{H}_{2} \mathrm{O}(1.0 \mathrm{~mL})$ by stirring for $15 \mathrm{~min}$. Then, the dispersion was loaded into a teflon-lined stainless steel autoclave of $10 \mathrm{~mL}$ volume. The sealed autoclave was heated under autogenous pressure at $150^{\circ} \mathrm{C}$ for 6 days. Upon cooling to room temperature, yellow block crystals of 1 were filtered off, washed with ethanol, and dried under a vacuum at room temperature $(46 \%$ yield based on $\mathrm{GeO}_{2}$ ). Elemental analysis for $\mathrm{C}_{4} \mathrm{H}_{24} \mathrm{~N}_{4} \mathrm{Ge}_{2}$ $\mathrm{Se}_{6}$ (1) (747.21): Anal. Calc.: C, 6.43; H, 3.24; N, 7.50 (\%). Found: C, 6.31; H, 3.19; N, 7.38 (\%). IR (KBr disk, $\mathrm{cm}^{-1}$ ): 3301 (s), $3074(\mathrm{w}), 2925$ (s), 2850 (s), 2652 (w), 1550 (s), 1504 (s), 1149 (s), 1341 (s), 1281 (s), 1222 (s), 1181 (s),1106 (m), 983 (m), 886 (m), 849 (m), 771 (m), $551(\mathrm{~m})$.

$2.1 \mathrm{~b}$ Synthesis of $\left[\mathrm{Ni}(\text { dien })_{2}\right]_{2} \mathrm{Ge}_{2} \mathrm{Se}_{5}\left(\mathrm{Se}_{2}\right)(2): \mathrm{GeO}_{2}$ (52 mg, $0.5 \mathrm{mmol}$ ), Se (156 mg, $2 \mathrm{mmol}$ ), and $\mathrm{NiCl}_{2}$. $6 \mathrm{H}_{2} \mathrm{O}(119 \mathrm{mg}, 0.5 \mathrm{mmol})$ were dispersed in diethylenetriamine (dien) $(2.0 \mathrm{~mL})$ and $\mathrm{CH}_{3} \mathrm{OH}(1.0 \mathrm{~mL})$ by stirring for $15 \mathrm{~min}$. Then, the dispersion was loaded into a teflon-lined stainless steel autoclave of $10 \mathrm{~mL}$ volume. The sealed autoclave was heated under autogenous pressure at $170^{\circ} \mathrm{C}$ for 6 days. Upon cooling to room temperature, orange-red block crystals of 2 were filtered off, washed with ethanol, and dried under a vacuum at room temperature $\left(58 \%\right.$ yield based on $\mathrm{GeO}_{2}$ ). Elemental analysis for $\mathrm{C}_{16} \mathrm{H}_{52} \mathrm{~N}_{12} \mathrm{Ni}_{2} \mathrm{Ge}_{2} \mathrm{Se}_{7}$ (2) (1228.02): Anal. Calc.: C, 15.65; H, 4.27; N, 13.69 (\%). Found: C, 15.42; H, 4.09; N, 13.55 (\%). IR (KBr disk, $\mathrm{cm}^{-1}$ ): 3248 (s), 2928 (s), 1572 (s), 1504 (s), 1378 (m), 1326 (s), $1214(\mathrm{w}), 1154(\mathrm{w}), 1009(\mathrm{~m}), 957$ (m), $815(\mathrm{w})$, $614(\mathrm{~m}), 584(\mathrm{~m}), 484$ (w), 435 (w). 2.1c Synthesis of $\left[\{\mathrm{Ni}(\text { tepa })\}_{2}\left(\mu-\mathrm{Ge}_{2} \mathrm{Se}_{6}\right)\right](3)$ : Purple crystals of compound 3 (62\% yield based on $\mathrm{GeO}_{2}$ ) were prepared by a procedure similar to that of the synthesis of $\mathbf{2}$, except that tetraethylenepentamine (tepa) was used instead of dien. Elemental analysis for $\mathrm{C}_{16} \mathrm{H}_{46} \mathrm{~N}_{10} \mathrm{Ni}_{2} \mathrm{Ge}_{2} \mathrm{Se}_{6}$ (3) (1114.99): Anal. Calc.: C, 17.24; H, 4.16; N, 12.56 (\%). Found: C, 17.11; H, 3.95; $\mathrm{N}, 12.41(\%)$. IR (KBr disk, $\left.\mathrm{cm}^{-1}\right): 3241$ (s), 3115 (s), 2939 (m), 2868 (m), 2212 (w), 1598 (s), 1492 (m), 1348 (m), $1318(\mathrm{~m}), 1154(\mathrm{w}), 1080(\mathrm{~m}), 1027$ (s), $823(\mathrm{w})$, 778 (w), 636 (s), $517(\mathrm{w}), 435(\mathrm{~m})$.

\subsection{Materials, instruments, and analytical methods}

All solvents and reagents for synthesis were of analytical grade and were used as received. Elemental analyses $(\mathrm{C}, \mathrm{H}, \mathrm{N})$ were performed using an EA1110-CHNS-O elemental analyzer. Fourier transform infrared (FT-IR) spectra were recorded with a Nicolet Magna-IR 550 spectrometer using dry $\mathrm{KBr}$ discs over the $4000-400 \mathrm{~cm}^{-1}$ range. Optical diffuse reflectance spectra of powder samples were obtained with a Shimadzu UV-3150 spectrometer at room temperature. Absorption $(\alpha / \mathrm{S})$ data were calculated from the reflectance using the KubelkaMunk function $\alpha / \mathrm{S}=(1-\mathrm{R})^{2} / 2 \mathrm{R} .{ }^{46}$ Thermogravimetric analysis (TGA) was conducted on a TG 3600 microanalyzer and the samples were heated at a rate of $5^{\circ} \mathrm{C}$ $\mathrm{min}^{-1}$ under a nitrogen stream of $100 \mathrm{~mL} \mathrm{~min}{ }^{-1}$.

\section{$2.3 \quad$ X-ray diffraction}

Single-crystal X-ray diffraction data for compounds 1-3 were collected on a Rigaku Saturn (1 and 3) or Rigaku Mercury (2) CCD diffractometer at 223(2) K. Data were collected using graphite-monochromated Mo-K $\alpha$ radiation $(\lambda=0.71073 \AA)$ with a $\omega$-scan method to a maximum $2 \theta$ value of $50.70^{\circ}$ for $\mathbf{1 - 2}$, and $50^{\circ}$ for $\mathbf{3}$ and were corrected for radiation absorption by methods incorporated in the diffractometer software. The structures were solved with direct methods using the program of SHELXS-97, ${ }^{47}$ and the refinement was performed against $F^{2}$ using the program of SHELXL-97.48 All non-hydrogen atoms were refined with anisotropic displacement parameters. The positions of hydrogen atoms were calculated theoretically. X-ray collection data and selected refinement results are summarized in Table 1.

\section{Results and Discussion}

\subsection{Syntheses and Infrared Spectra}

Title compounds were prepared under solvothermal conditions. Reaction of $\mathrm{GeO}_{2}$, Se and $\mathrm{NH}_{4} \mathrm{Cl}$ in a 1:4:2 
Table 1. Crystal data and structure refinement for $\mathbf{1}-\mathbf{3}$.

\begin{tabular}{|c|c|c|c|}
\hline Compounds & 1 & 2 & 3 \\
\hline Formula & $\mathrm{C}_{4} \mathrm{H}_{24} \mathrm{~N}_{4} \mathrm{Ge}_{2} \mathrm{Se}_{6}$ & $\mathrm{C}_{16} \mathrm{H}_{52} \mathrm{~N}_{12} \mathrm{Ni}_{2} \mathrm{Ge}_{2} \mathrm{Se}_{7}$ & $\mathrm{C}_{16} \mathrm{H}_{46} \mathrm{~N}_{10} \mathrm{Ni}_{2} \mathrm{Ge}_{2} \mathrm{Se}_{6}$ \\
\hline$M \mathrm{r}$ & 747.21 & 1228.02 & 1114.99 \\
\hline Crystal system & Monoclinic & Monoclinic & Tetragonal \\
\hline Space group & $P 2{ }_{1} / \mathrm{n}$ & $P 2{ }_{1} / \mathrm{c}$ & $I 4_{1} / \mathrm{a}$ \\
\hline$a(\AA)$ & $13.503(3)$ & $15.741(3)$ & $26.001(3)$ \\
\hline$b(\AA)$ & $7.7775(16)$ & $14.463(3)$ & $26.001(3)$ \\
\hline$c(\AA)$ & $19.583(4)$ & $16.390(3)$ & $9.7079(12)$ \\
\hline$\alpha\left(^{\circ}\right)$ & 90 & 90 & 90 \\
\hline$\beta\left(^{\circ}\right)$ & $106.03(3)$ & $103.03(3)$ & 90 \\
\hline$\gamma\left({ }^{\circ}\right)$ & 90 & 90 & 90 \\
\hline$V\left(\AA^{3}\right)$ & $1976.6(7)$ & $3635.2(13)$ & $6562.9(14)$ \\
\hline $\mathrm{Z}$ & 4 & 4 & 8 \\
\hline$D_{\text {calcd }}\left(\mathrm{g} \mathrm{cm}^{-3}\right)$ & 2.511 & 2.244 & 2.257 \\
\hline$F(000)$ & 1376 & 2360 & 4288 \\
\hline Goodness-of-fit on $F^{2}$ & 1.124 & 1.153 & 1.115 \\
\hline Final $R$ indices $[I>2 \sigma(I)]$ & $\begin{array}{l}R_{1}=0.0460 \\
w R_{2}=0.1049\end{array}$ & $\begin{array}{l}R_{1}=0.0490 \\
w R_{2}=0.0937\end{array}$ & $\begin{array}{l}R_{1}=0.0497 \\
w R_{2}=0.0953\end{array}$ \\
\hline$R$ indices (all data) & $\begin{array}{l}R_{1}=0.0507 \\
w R_{2}=0.1168\end{array}$ & $\begin{array}{l}R_{1}=0.066 \\
w R_{2}=0.1113\end{array}$ & $\begin{array}{l}R_{1}=0.0543 \\
w R_{2}=0.1010\end{array}$ \\
\hline
\end{tabular}

molar ratio in $\left(\mathrm{CH}_{3}\right)_{2} \mathrm{NH}(70 \%)$ aqueous solution at $150^{\circ} \mathrm{C}$ for 6 days produced yellow crystals of 1 . The reaction without $\mathrm{NH}_{4} \mathrm{Cl}$ produced amorphous phase of black powder and no crystalline compound was obtained. Similar synthesis using $\mathrm{CH}_{3} \mathrm{NH}_{2}$ instead of $\left(\mathrm{CH}_{3}\right)_{2} \mathrm{NH}$ failed to give crystalline compound. The $\mathrm{NH}_{4}^{+}$ion may maintain an appropriate $\mathrm{pH}$ value of the solution in the reaction. In addition, it acts as a counter cation in the final product. $\mathrm{CH}_{3} \mathrm{OH}$ was necessary for the synthesis of polyselenidogermanate $\left[\mathrm{Ni}(\mathrm{dien})_{2}\right]_{2} \mathrm{Ge}_{2}$ $\mathrm{Se}_{5}\left(\mathrm{Se}_{2}\right)$ (2). The reaction without addition of $\mathrm{CH}_{3} \mathrm{OH}$ produced amorphous powder. However, the reaction $\mathrm{GeO}_{2}, \mathrm{Se}$, and $\mathrm{FeCl}_{2} \cdot 4 \mathrm{H}_{2} \mathrm{O}$ in dien without $\mathrm{CH}_{3} \mathrm{OH}$ afforded selenidogermanate compound $\left[\mathrm{Fe}(\mathrm{dien})_{2}\right]_{2}$ $\mathrm{Ge}_{2} \mathrm{Se}_{6} \cdot{ }^{31}$ Compound 3 was prepared in a tepa $/ \mathrm{CH}_{3} \mathrm{OH}$ mixed solution. The reaction without $\mathrm{CH}_{3} \mathrm{OH}$ also produced the same compound $\mathbf{3}$, but the yield decreased to $32 \%$. The purity of bulk phases of compounds $\mathbf{1}-\mathbf{3}$ were investigated using powder X-ray diffraction (PXRD). The PXRD patterns of the bulk phases are consistent with the simulated PXRD patterns based on singlecrystal XRD data (Figures S1-S3 in the Supplementary Information), respectively.

In the IR spectra of title compounds (Figures S4-S6, in SI), the absorption peaks located in the frequency range $3074-3301 \mathrm{~cm}^{-1}$ could be assigned to the asymmetric and symmetric $\mathrm{N}-\mathrm{H}$ stretching vibrations of the amino groups of $\left[\mathrm{H}_{2} \mathrm{~N}\left(\mathrm{CH}_{3}\right)_{2}\right]^{+}$, dien or tepa. The $\mathrm{C}-$ $\mathrm{H}$ stretching vibrations occur between 2850 and 2939 $\mathrm{cm}^{-1}$. The $\mathrm{N}-\mathrm{H}$ and $\mathrm{C}-\mathrm{H}$ deformation modes occur in the range $1550-1598 \mathrm{~cm}^{-1}$ and $1492-1504 \mathrm{~cm}^{-1}$,

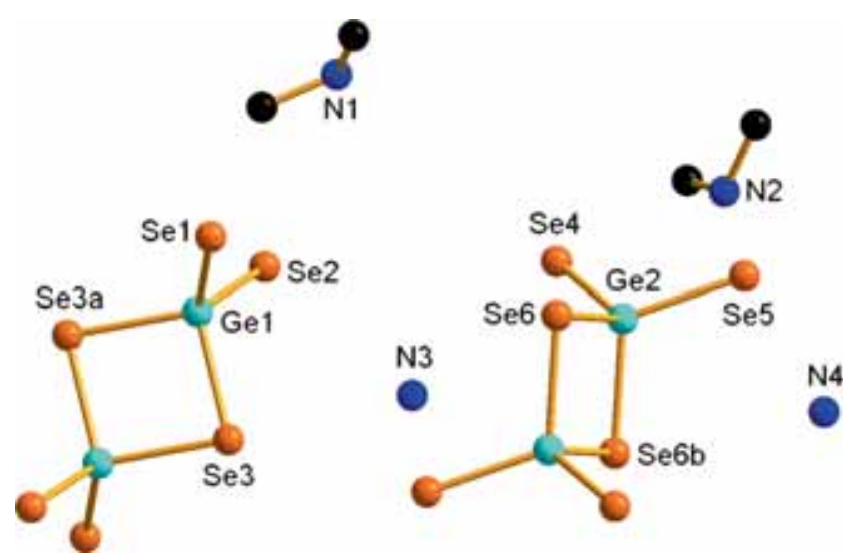

Figure 1. Crystal structure of $\mathbf{1}$ with the labeling scheme. Hydrogen atoms are omitted for clarity.

respectively. The strong bands in 1009-1027 $\mathrm{cm}^{-1}$ could be assigned to $\mathrm{C}-\mathrm{N}$ stretching vibrations.

\subsection{Structure description}

3.2a $\left[\mathrm{NH}_{4}\right]_{2}\left[\mathrm{H}_{2} \mathrm{~N}\left(\mathrm{CH}_{3}\right)_{2}\right]_{2} \mathrm{Ge}_{2} \mathrm{Se}_{6}(\mathbf{1})$ : Compound $\mathbf{1}$ crystallizes in the monoclinic crystal system with space group $P 2{ }_{1} / \mathrm{n}$ with four formula units in the unit cell (Table 1). The crystal structure consists of discrete dimeric $\left[\mathrm{Ge}_{2} \mathrm{Se}_{6}\right]^{4-}$ anions with charge compensating cations $\left[\mathrm{NH}_{4}\right]^{+}$and $\left[\mathrm{H}_{2} \mathrm{~N}\left(\mathrm{CH}_{3}\right)_{2}\right]^{+}$(Figure 1). There are two crystallographically independent $\mathrm{Ge}^{4+}$, and six $\mathrm{Se}^{2-}$ ions in 1. Both $\mathrm{Ge}(1)^{4+}$ and $\mathrm{Ge}(2)^{4+}$ ions are coordinated to four $\mathrm{Se}^{2-}$ anions forming $\mathrm{GeSe}_{4}$ tetrahedra. Two tetrahedral $\mathrm{Ge}(1) \mathrm{Se}_{4}$ units are joined 


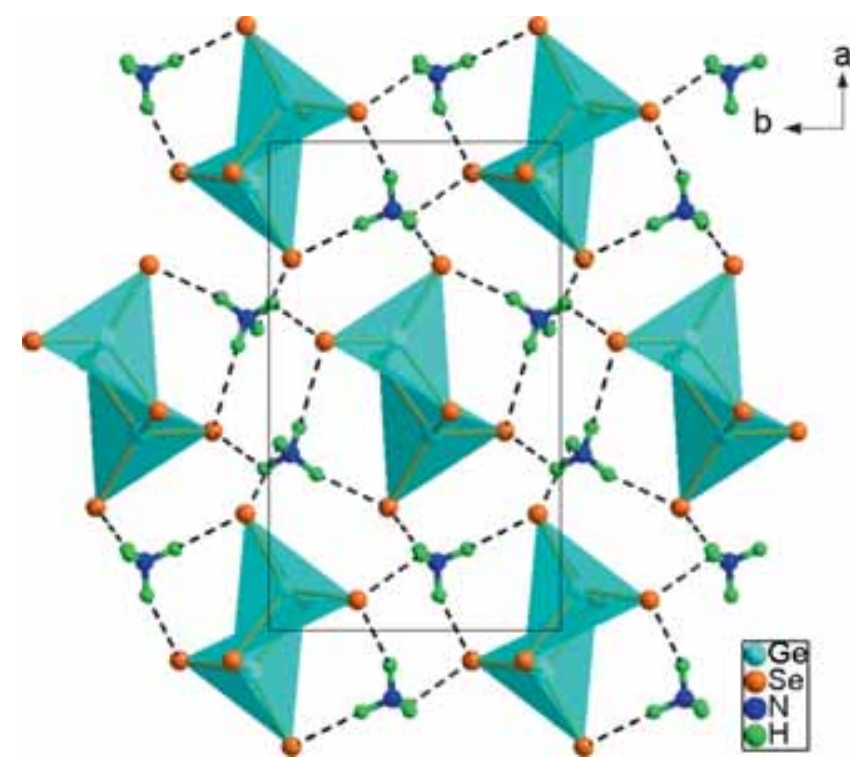

Figure 2. A view of the layer assembled by $\left[\mathrm{Ge}_{2} \mathrm{Se}_{6}\right]^{4-}$ and $\left[\mathrm{NH}_{4}\right]^{+}$ions via $\mathrm{N}-\mathrm{H}$. . S Se H-bonding (shown in dashed lines) in 1. Cyan tetrahedron: $\mathrm{GeSe}_{4}$.

Table 2. Selected bond lengths $(\AA)$ and angles $\left(^{\circ}\right)$ for $\mathbf{1}$.

$\begin{array}{ll}{ }^{a} \mathrm{Ge}_{-} \mathrm{Se}_{\mathrm{b}} & 2.3935(17)-2.4051(16) \\ { }^{b} \mathrm{Ge}-\mathrm{Se}_{\mathrm{t}} & 2.2929(17)-2.3121(18) \\ \mathrm{Se}_{\mathrm{t}}-\mathrm{Ge}_{-} \mathrm{Se}_{\mathrm{t}} & 113.37(7), 113.96(7) \\ \mathrm{Se}_{\mathrm{t}}-\mathrm{Ge}-\mathrm{Se}_{\mathrm{b}} & 109.00(6)-113.62(7) \\ \mathrm{Se}_{\mathrm{b}}-\mathrm{Ge}-\mathrm{Se}_{\mathrm{b}} & 95.07(6), 95.45(6) \\ \mathrm{Ge}-\mathrm{Se}-\mathrm{Ge} & 84.55(6), 84.93(6)\end{array}$

${ }^{a}$ Terminal and ${ }^{b}$ bridging Ge-Se bond lengths of $\left[\mathrm{Ge}_{2} \mathrm{Se}_{6}\right]^{4-}$ unit.

via edge-sharing, forming a dimeric $\left[\mathrm{Ge}_{2} \mathrm{Se}_{6}\right]^{4-}$ anion (Figure 1). Another $\left[\mathrm{Ge}_{2} \mathrm{Se}_{6}\right]^{4-}$ anion is formed by two $\mathrm{Ge}(2) \mathrm{Se}_{4}$ units with the same connection modes. In the $\left[\mathrm{Ge}_{2} \mathrm{Se}_{6}\right]^{4-}$ anions, the $\mathrm{Ge}-\mathrm{Se}_{\mathrm{b}}$ bridging bond lengths vary range from $2.3935(17)$ to $2.4051(16) \AA$, which are longer than the $\mathrm{Ge}-\mathrm{Se}_{\mathrm{t}}$ terminal bond lengths $\left[\mathrm{Ge}-\mathrm{Se}_{\mathrm{t}}\right.$ : 2.2929(17)-2.3121(18) ̊] (Table 2 and Table S1 in SI). The distances of the two kinds of bonds are consistent with the corresponding values in other compounds containing the $\left[\mathrm{Ge}_{2} \mathrm{Se}_{6}\right]^{4-}$ anions. ${ }^{19,31,32,49}$ The Se-Ge-Se angles range from $95.07(6)$ to $113.96(7)^{\circ}$, indicating the distorted tetrahedral geometry for the $\mathrm{GeSe}_{4}$ units. The $\mathrm{Se}-\mathrm{Ge}-\mathrm{Se}$ angles increase in the order: $\mathrm{Se}_{\mathrm{b}}-\mathrm{Ge}_{-}-\mathrm{Se}_{\mathrm{b}}>$ $\mathrm{Se}_{\mathrm{t}}-\mathrm{Ge}-\mathrm{Se}_{\mathrm{b}}>\mathrm{Se}_{\mathrm{t}}-\mathrm{Ge}-\mathrm{Se}_{\mathrm{t}}$ (Table 2).

In 1 , the $\left[\mathrm{NH}_{4}\right]^{+}$and $\left[\mathrm{H}_{2} \mathrm{~N}\left(\mathrm{CH}_{3}\right)_{2}\right]^{+}$counter ions contact $\left[\mathrm{Ge}_{2} \mathrm{Se}_{6}\right]^{4-}$ anion via $\mathrm{N}-\mathrm{H}$. . Se with $\mathrm{N}$. . Se separation varying in the range of 3.438(12)-3.502(12) $\AA$ (Table S4 in SI), indicating intermolecular $\mathrm{N}-\mathrm{H} \cdots \mathrm{Se}$ hydrogen bond interactions, which result in a 3-D Hbonding network. Each $\left[\mathrm{NH}_{4}\right]^{+}$cation contacts three $\left[\mathrm{Ge}_{2} \mathrm{Se}_{6}\right]^{4-}$ anions via $\mathrm{N}-\mathrm{H} \cdots \mathrm{Se}$ bonding, whereas

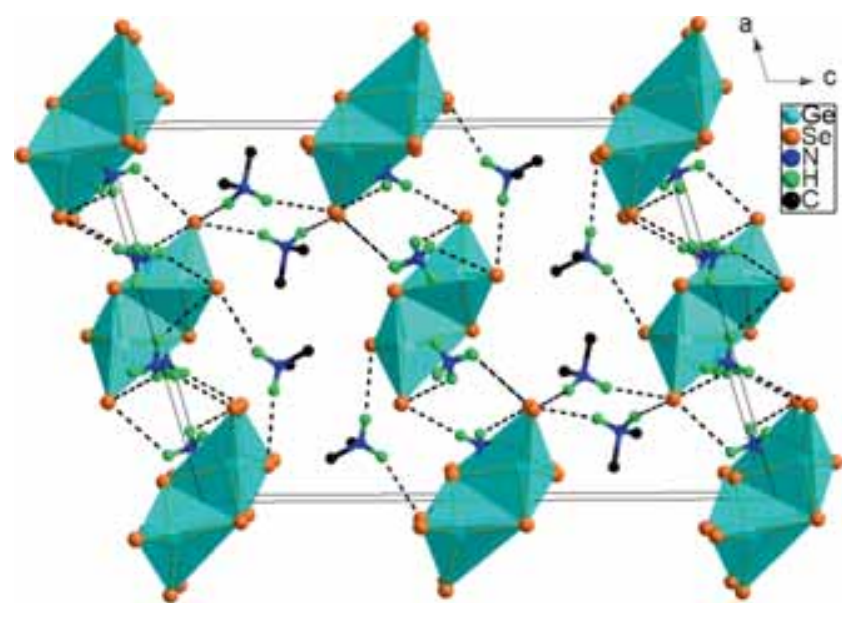

Figure 3. Crystal packing diagram of $\mathbf{1}$, showing intermolecular $\mathrm{N}-\mathrm{H} \cdots$ Se hydrogen bonds. Hydrogen atoms of $\mathrm{CH}_{3}$ are omitted for clarity. Cyan tetrahedron: $\mathrm{GeSe}_{4}$.

each $\left[\mathrm{Ge}_{2} \mathrm{Se}_{6}\right]^{4-}$ anion interacts six $\left[\mathrm{NH}_{4}\right]^{+}$cations. As a result, the $\left[\mathrm{NH}_{4}\right]^{+}$and $\left[\mathrm{Ge}_{2} \mathrm{Se}_{6}\right]^{4-}$ ions form a $\left\{\left(\left[\mathrm{NH}_{4}\right]^{+}\right)_{2} /\left[\mathrm{Ge}_{2} \mathrm{Se}_{6}\right]^{4-}\right\}$ anionic layer perpendicular to the $c$ axis via these $\mathrm{N}-\mathrm{H} \cdots \mathrm{Se}$ hydrogen bonds (Figure 2). Two protonated $\left[\mathrm{H}_{2} \mathrm{~N}\left(\mathrm{CH}_{3}\right)_{2}\right]^{+}$ions are located between the $\left\{\left(\left[\mathrm{NH}_{4}\right]^{+}\right)_{2} /\left[\mathrm{Ge}_{2} \mathrm{Se}_{6}\right]^{4-}\right\}$ anionic layers. They interact with the layers through $\mathrm{N}-\mathrm{H} \cdots \mathrm{Se}$ $\mathrm{H}$-bonds, resulting in a 3-D H-bonding network (Figure 3). All terminal $\mathrm{Se}$ atoms of $\left[\mathrm{Ge}_{2} \mathrm{Se}_{6}\right]^{4-}$ are involved in the $\mathrm{H}$-bonding interaction, and each $\left[\mathrm{Ge}_{2} \mathrm{Se}_{6}\right]^{4-}$ anion contacts six $\left[\mathrm{NH}_{4}\right]^{+}$and two $\left[\mathrm{H}_{2} \mathrm{~N}\left(\mathrm{CH}_{3}\right)_{2}\right]^{+}$cations (Figure $\mathrm{S} 7 \mathrm{in} \mathrm{SI}$ ).

3.2b [Ni(dien $\left.)_{2}\right]_{2} \mathrm{Ge}_{2} \mathrm{Se}_{5}\left(\mathrm{Se}_{2}\right) \quad$ (2): Compound 2 crystallizes in the monoclinic crystal system with space group $P 2{ }_{1} / \mathrm{c}$ with four formula units in the unit cell (Table 1). It consists of a dimeric polyselenidogermanate $\left[\mathrm{Ge}_{2} \mathrm{Se}_{7}\right]^{4-}$ anion and two $\left[\mathrm{Ni}(\text { dien })_{2}\right]^{2+}$ cations (Figure 4). $\mathrm{Ge}(1)^{4+}$ and $\mathrm{Ge}(2)^{4+}$ ions both coordinate with four $\mathrm{Se}^{2-}$ atoms to form two tetrahedral $\mathrm{GeSe}_{4}$ units. The two $\mathrm{GeSe}_{4}$ units are connected sharing a corner and a $\mathrm{Se}-\mathrm{Se}$ bond (Figure 4), forming a $\left[\mathrm{Ge}_{2} \mathrm{Se}_{5}\left(\mathrm{Se}_{2}\right)\right]^{4-}$ dimeric anion (Figure 4a). As a result, a five-membered ring $\mathrm{Ge}_{2} \mathrm{Se}_{3}$ is formed in the anion. The $\mathrm{Ge}-\mathrm{Se}-\mathrm{Ge}$ bond angle $\left[106.33(9)^{\circ}\right]$ of $\left[\mathrm{Ge}_{2} \mathrm{Se}_{5}\right.$ $\left.\left(\mathrm{Se}_{2}\right)\right]^{4-}$ is much larger than the corresponding angle of the dimeric $\left[\mathrm{Ge}_{2} \mathrm{Se}_{6}\right]^{4-}\left[84.55(6)^{\circ}\right.$ and 84.93(6) $\left.{ }^{\circ}\right]$ anion in 1 , because the $\left[\mathrm{Ge}_{2} \mathrm{Se}_{6}\right]^{4-}$ anion contains a fourmembered straining ring $\mathrm{Ge}_{2} \mathrm{Se}_{2}$. The terminal and bridging $\mathrm{Ge}-\mathrm{Se}$ bond lengths are 2.283(3)-2.306(3) $\AA$ and 2.399(3)-2.421(3) $\AA$ (Table 3), respectively, and the $\mathrm{Se}-\mathrm{Se}$ bond distance is 2.325(3) $\AA$. Both $\mathrm{Ge}-\mathrm{Se}$ and $\mathrm{Se}-\mathrm{Se}$ bond lengths are consistent with the corresponding values found in the compounds $\left(\mathrm{enH}_{2}\right)$ 


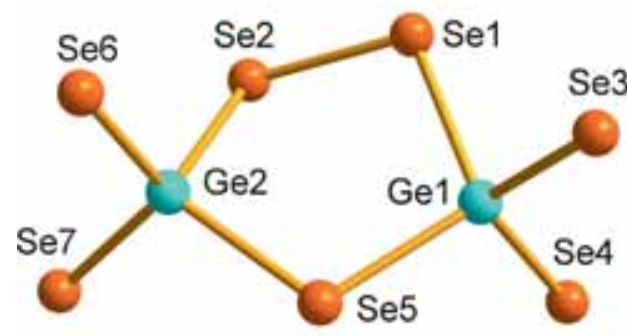

(a)

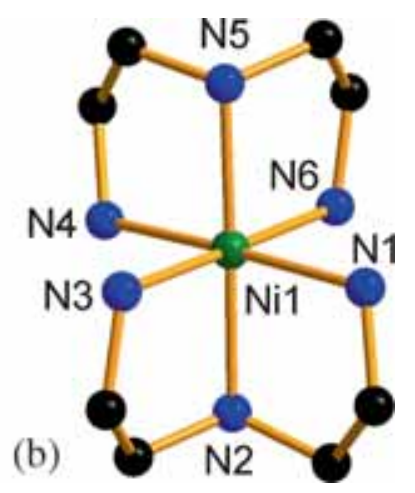

Figure 4. Crystal structures of the $\left[\mathrm{Ge}_{2} \mathrm{Se}_{7}\right]^{4-}$ anion (a), and $[\mathrm{Ni}(1)$ $\left.(\text { dien })_{2}\right]^{2+}$ cation (b) in $\mathbf{2}$. Hydrogen atoms are omitted for clarity.

Table 3. Selected bond lengths $(\AA)$ and angles $\left({ }^{\circ}\right)$ for 2 and 3 .

\begin{tabular}{lcc}
\hline & \multicolumn{1}{c}{$\mathbf{2}$} & $\mathbf{3}$ \\
\hline${ }^{a} \mathrm{Ge}_{-} \mathrm{Se}_{\mathrm{b}}$ & $2.399(3)-2.421(3)$ & $2.335(3)-2.338(3)$ \\
${ }^{b} \mathrm{Ge}-\mathrm{Se}_{\mathrm{t}}$ & $2.283(3)-2.306(3)$ & $2.259(2)-2.288(2)$ \\
$\mathrm{Se}-\mathrm{Se}$ & $2.325(3)$ & \\
$\mathrm{Ni}-\mathrm{Se}$ & & $2.666(2)$ \\
$\mathrm{Ni}-\mathrm{N}$ & $2.076(14)-2.149(15)$ & $2.118(11)-2.169(11)$ \\
$\mathrm{Se}-\mathrm{Ge}-\mathrm{Se}$ & $97.65(10)-116.43(11)$ & $95.38(9)-114.78(8)$ \\
$\mathrm{Ge}-\mathrm{Se}-\mathrm{Ge}$ & $106.33(9)$ & $84.62(9)$ \\
$\mathrm{Ge}-\mathrm{Se}-\mathrm{Ni}$ & & $111.02(8)$ \\
$\mathrm{N}-\mathrm{Ni}-\mathrm{N}(\mathrm{Se})$ & $82.2(6)-178.4(7)$ & $77.1(5)-166.8(5)$ \\
\hline
\end{tabular}

${ }^{a}$ Terminal and ${ }^{b}$ bridging Ge-Se bond lengths of $\left[\mathrm{Ge}_{2} \mathrm{Se}_{7}\right]^{4-}$ in $\mathbf{2}$ and $\left[\mathrm{Ge}_{2} \mathrm{Se}_{6}\right]^{4-}$ in $\mathbf{3}$.

$\left[\left\{\mathrm{Mn}(\mathrm{en})_{2}(\mathrm{enH})\right\}_{2}(\mu\right.$-en $\left.)\right]\left(\mathrm{Ge}_{2} \mathrm{Se}_{7}\right),{ }^{37}(1,2-\mathrm{dapH})_{2}\{[\mathrm{Mn}$ (1,2-dap $\left.\left.)_{2}\right] \mathrm{Ge}_{2} \mathrm{Se}_{7}\right\}$, and $\left[\{\mathrm{Mn}(\text { cyclam })\}_{2}\left(\mu-\mathrm{Ge}_{2} \mathrm{Se}_{7}\right)\right]$. $\mathrm{CH}_{3} \mathrm{OH} \cdot 1.5 \mathrm{H}_{2} \mathrm{O} .{ }^{42}$

The $\mathrm{Ni}(1)^{2+}$ ion is 6-fold coordinated by two tridentate dien ligands to form a distorted octahedral $\left[\mathrm{Ni}(\text { dien })_{2}\right]^{2+}$ cation (Figure $\left.4 \mathrm{~b}\right)$. The $\left[\mathrm{Ni}(1)(\text { dien })_{2}\right]^{2+}$ cation shows the symmetrical facial ( $s f a c$ ) geometry. The $\mathrm{Ni}(2)^{2+}$ ion also forms an octahedral $\left[\mathrm{Ni}(\text { dien })_{2}\right]^{2+}$ cation in sfac configuration with two dien ligands (Figure $\mathrm{S} 8$ in $\mathrm{SI}$ ). The $\mathrm{Ni}-\mathrm{N}$ bond lengths are in the range of 2.076(14)-2.149(15) $\AA$ (Table 3), which are comparable to the $\mathrm{Ni}-\mathrm{N}$ bond lengths observed in compounds containing $\left[\mathrm{Ni}(\mathrm{dien})_{2}\right]^{2+}$ complex. ${ }^{34,43}$ The $\left[\mathrm{Ni}(\mathrm{dien})_{2}\right]^{2+}$ cation contacts $\left[\mathrm{Ge}_{2} \mathrm{Se}_{7}\right]^{4-}$ anions via $\mathrm{N}-\mathrm{H}$-..S Se H-bonds, forming a layer perpendicular to the $a$ axis (Figure 5). The layers are further connected to a 3-D network via $\mathrm{N}-\mathrm{H}$. . Se H-bonds between the layers (Figure S9 in SI). The N $\cdots$ Se distances and $\mathrm{N}-\mathrm{H} \cdots \mathrm{Se}$ angles vary in the range of 3.434(17)-3.754(15) $\AA$ and $136.6-174.0^{\circ}$, respectively (Table S4 in SI).

The ternary system $\mathrm{TM} / \mathrm{Ge} / \mathrm{E}(\mathrm{E}=\mathrm{S}, \mathrm{Se})$ has been investigated in different ethylene polyamines under solvothermal conditions, and a number of TM(II)-con-

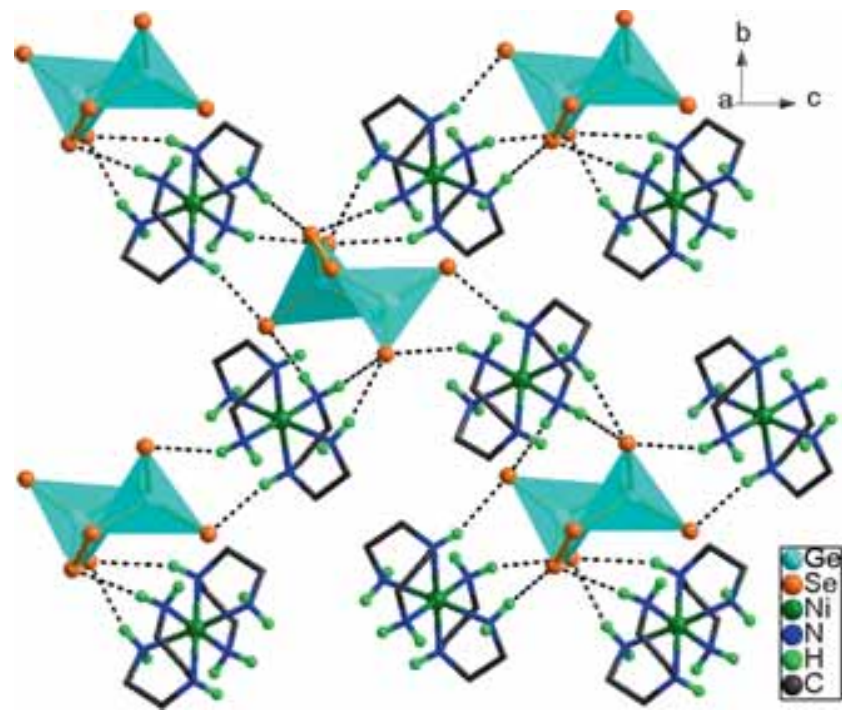

Figure 5. A sectional crystal packing diagram of 2, showing intermolecular $\mathrm{N}-\mathrm{H} \cdots$ Se hydrogen bonds. Hydrogen atoms of $\mathrm{CH}_{2}$ are omitted for clarity. Cyan tetrahedron: $\mathrm{GeSe}_{4}$.

taining selenidogermanates decorated with polyamines at TM center have been prepared. Dimeric $\left[\mathrm{Ge}_{2} \mathrm{E}_{6}\right]^{4-}$ and tetrameric $\left[\mathrm{Ge}_{4} \mathrm{E}_{10}\right]^{4-}$ anions are the dominant selenidogermanate aggregates in the solvothermal syntheses. ${ }^{30-32,36,43,44}$ It is notable that polyselenidogermanate $\left[\mathrm{Ge}_{2} \mathrm{Se}_{7}\right]^{4-}$ anion is only obtained using $\mathrm{Mn}(\mathrm{II})$-polyamine complex as the structure-directing agent. Free $\left[\mathrm{Ge}_{2} \mathrm{Se}_{7}\right]^{4-}$ anion is observed in compounds $\left(\mathrm{enH}_{2}\right)\left[\left\{\mathrm{Mn}(\mathrm{en})_{2}(\mathrm{enH})\right\}_{2}(\mu\right.$-en $\left.)\right]\left(\mathrm{Ge}_{2} \mathrm{Se}_{7}\right)_{2}$ and $\left[\mathrm{Mn}(\mathrm{dien})_{2}\right]_{2} \mathrm{Ge}_{2} \mathrm{Se}_{7} \cdot{ }^{37} \mathrm{But}$ the $\left[\mathrm{Ge}_{2} \mathrm{Se}_{7}\right]^{4-}$ anion is distorted with $\left[\mathrm{Ge}_{2} \mathrm{Se}_{6}\right]^{4-}$ unit in the former, and with $\left[\mathrm{Ge}_{2} \mathrm{Se}_{8}\right]^{4-}$ unit in the latter. Using 1,4,8,11-tetraazacyclotetradecane (cyclam) and 1,2-propanediamine (1,2-dap) as ligands to $\mathrm{Mn}$ (II) centers, $\mathrm{Mn}-\mathrm{Ge}_{2} \mathrm{Se}_{7} \mathrm{com}$ plexes are obtained. ${ }^{38,42}$ Compound $\mathbf{2}$ is the first example of $\left[\mathrm{Ge}_{2} \mathrm{Se}_{7}\right]^{4-}$ anion with counter cation other than the $\mathrm{Mn}(\mathrm{II})$-complex. 


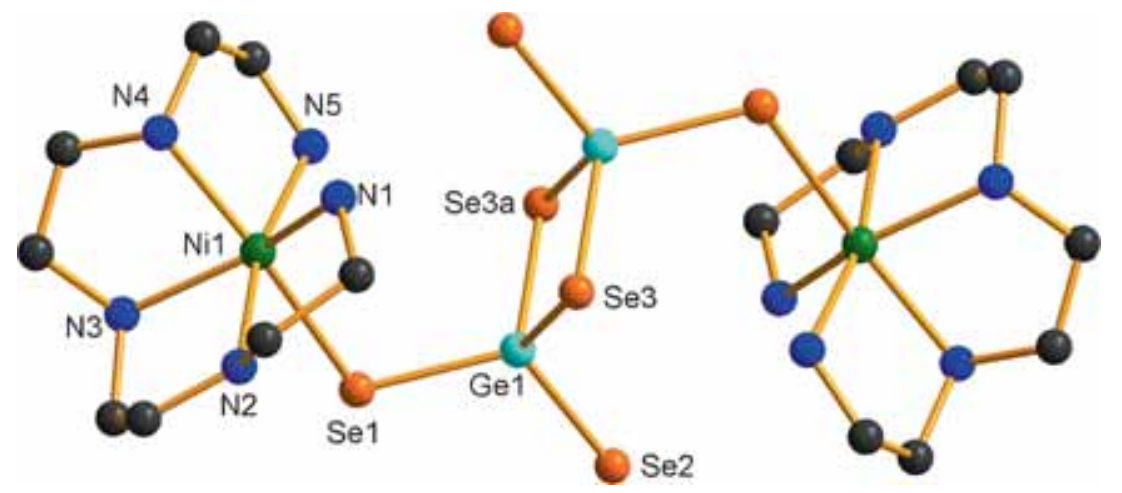

Figure 6. Crystal structure of $\mathbf{3}$ with the labeling scheme. Hydrogen atoms are omitted for clarity.

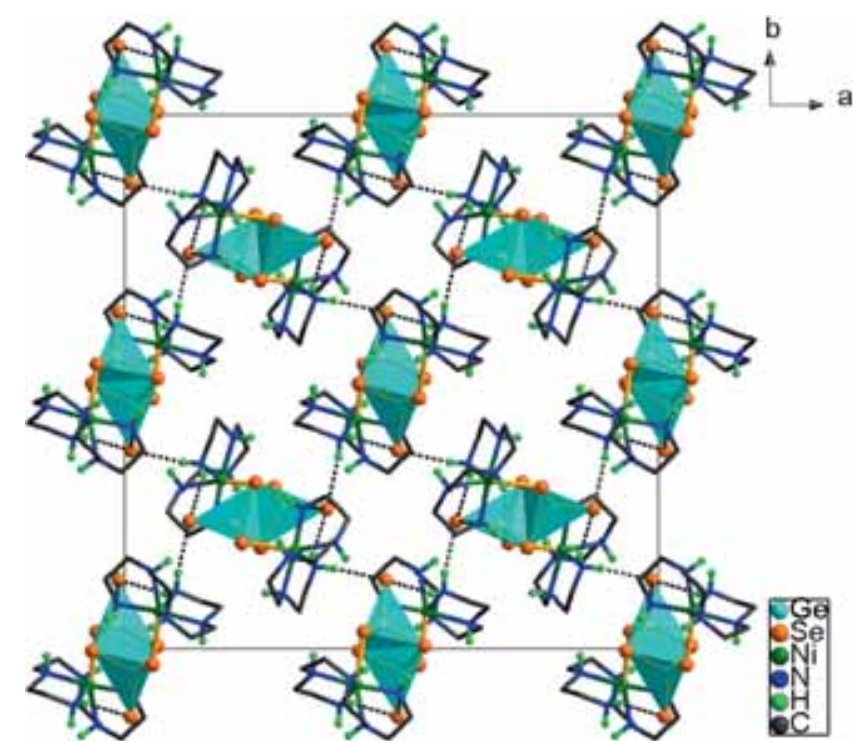

Figure 7. Crystal packing diagram of $\mathbf{3}$, showing intermolecular N-H. . Se hydrogen bonds. Hydrogen atoms of $\mathrm{CH}_{2}$ are omitted for clarity. Cyan tetrahedron: $\mathrm{GeSe}_{4}$.

3.2c $\quad\left[\{\mathrm{Ni}(\text { tepa })\}_{2}\left(\mu-\mathrm{Ge}_{2} \mathrm{Se}_{6}\right)\right](\mathbf{3}):$ Complex 3 crystallizes in the tetragonal space group $I 4_{1} / \mathrm{a}$ with eight formula units in the unit cell. It is isostructural to the compounds $\left[\{\mathrm{TM}(\text { tepa })\}_{2}\left(\mu-\mathrm{Ge}_{2} \mathrm{Se}_{6}\right)\right](\mathrm{TM}=\mathrm{Mn}$, $\mathrm{Fe}) .^{45} 3$ is composed from $\left[\mathrm{Ge}_{2} \mathrm{Se}_{6}\right]^{4-}$ and $\left[\mathrm{Ni}(\text { tepa }]^{2+}\right.$ fragments (Figure 6). The $\mathrm{Ni}^{2+}$ ion is coordinated to a tepa molecule to form a $[\mathrm{Ni} \text { (tepa) }]^{2+}$ unit. Acting as bidentate bridging ligand $\mu-\mathrm{Ge}_{2} \mathrm{Se}_{6}$, the $\left[\mathrm{Ge}_{2} \mathrm{Se}_{6}\right]^{4-}$ anion links two $[\mathrm{Ni}(\text { tepa })]^{2+}$ units via two trans terminal Se atoms, forming neutral binuclear complex $\mathbf{3}$. Because of the coordination, the tetrahedral $\mathrm{GeSe}_{4}$ units of $\mu-\mathrm{Ge}_{2} \mathrm{Se}_{6}$ in 3 are more distorted than the $\mathrm{GeSe}_{4}$ units of the discrete $\left[\mathrm{Ge}_{2} \mathrm{Se}_{6}\right]^{4-}$ anions in 1, manifested by the $\mathrm{Se}-\mathrm{Ge}-\mathrm{Se}$ bond angles (Tables 2 and 3 ). The $\mathrm{Ni}^{2+}$ ion is in a 6-fold coordinated environment involving five nitrogen atoms of a tepa ligand and one Se atom of the $\mathrm{Ge}_{2} \mathrm{Se}_{6}$ unit, resulting in an octahedron $\mathrm{NiN}_{5} \mathrm{Se}$. The $\mathrm{NiN}_{5} \mathrm{Se}$ octahedron is more distorted than the $\mathrm{NiN}_{6}$ octahedron in compound 2, as exhibited by

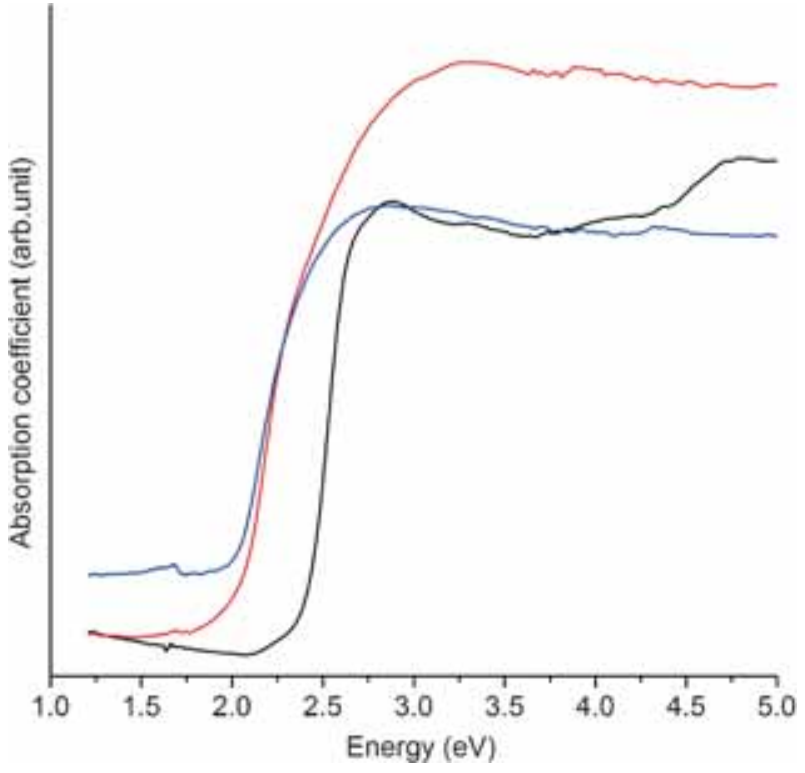

Figure 8. Solid state optical absorption spectra of compounds $\mathbf{1}$ (black), $\mathbf{2}$ (red), and $\mathbf{3}$ (blue).

their bond angles around the Ni(II) centers (Tables S2 and $\mathrm{S} 3$ in SI). In 3, all terminal Se atoms of $\mathrm{Ge}_{2} \mathrm{Se}_{6}$ unit are involved in weak $\mathrm{N}-\mathrm{H} \cdots \mathrm{Se}$ [3.401(12)3.654(12) $\AA$ and $149.5-168.3^{\circ}$ ] (Table S4 in SI) hydrogen bond interactions with four neighbor $\left[\{\mathrm{Ni}(\text { tepa })\}_{2}\right.$ $\left.\left(\mu-\mathrm{Ge}_{2} \mathrm{Se}_{6}\right)\right]$ molecules (Figure 7). The $\mathrm{N}-\mathrm{H} \cdots \mathrm{Se}$ hydrogen bonds connect the $\left[\{\mathrm{Ni} \text { (tepa) }\}_{2}\left(\mu-\mathrm{Ge}_{2} \mathrm{Se}_{6}\right)\right.$ molecules into a three-dimensional network (Figure S10 in SI).

\subsection{Optical Properties}

Solid-state optical absorption spectra of compounds 1-3 were recorded using powder samples at room temperature. The absorption data were converted from the diffuse-reflectance spectra by the KubelkaMunk function. ${ }^{46}$ The complexes exhibit well-defined steep absorption edges from which the optical band gaps $\left(E_{\mathrm{g}}\right)$ can be estimated at 2.35, 2.10 and 2.06 
$\mathrm{eV}$ for 1-3 (Figure 8), respectively, which indicate that these compounds exhibit possible semiconducting properties. Blue shift occurs from organic-hybrid selenidogermanate $\mathbf{1}$ to Ni-selenidogermanates $\mathbf{2}$ and 3. The band gap of $\mathbf{3}$ is higher than that of $\mathrm{S}$-analog $\left[\{\mathrm{Ni}(\text { tepa })\}_{2}\left(\mu-\mathrm{Ge}_{2} \mathrm{~S}_{6}\right)\right]\left(E_{\mathrm{g}}=2.48 \mathrm{eV}\right) .{ }^{44}$

\subsection{Thermal properties}

Thermal stabilities of compounds $\mathbf{1}-\mathbf{3}$ were investigated using thermogravimetric analysis (TGA) method under a nitrogen atmosphere (Figure S11 in SI). TGA curve shows that compound $\mathbf{1}$ exhibits a multi-step decomposition process with the total weight loss of $37.2 \%$ between $170^{\circ} \mathrm{C}$ and $310^{\circ} \mathrm{C}$. The total weight loss is in accordance with the release of two $\mathrm{NH}_{3}, \mathrm{H}_{2} \mathrm{Se}$, and $\mathrm{HN}\left(\mathrm{CH}_{3}\right)_{2}$ molecules. Compound 2 exhibits two overlapped decomposition processes between $210^{\circ} \mathrm{C}$ and $350^{\circ} \mathrm{C}$ with a total weight loss of $32.8 \%$, which corresponds to the losses of four dien (33.6\%) ligands. Compound $\mathbf{3}$ decomposes in one step with the weight loss of $32.5 \%$. The weight loss is in agreement with the loss of two tepa $(33.9 \%)$ molecules.

\section{Conclusions}

In summary, three new H-bond-based supramolecular selenidogermanates compounds (1-3) have been synthesized under solvothermal conditions and characterized. The formation of binary selenidogermanate units is influenced by the reaction media and counter cations. Compound 2 represents the first polyselenidogermanate anion of $\left[\mathrm{Ge}_{2} \mathrm{Se}_{7}\right]^{4-}$ with counter cations other than the Mn-complexes. The crystal structures of $\mathbf{2}$ and $\mathbf{3}$ indicate that complexation between the selenidogermanate anion and transition metal cations are related to the denticity of ethylene polyamines. Furthermore, the optical and thermal properties of the compounds $\mathbf{1}-\mathbf{3}$ were also investigated.

\section{Supplementary Information (SI)}

Crystallographic data for the crystal structures reported in this paper have been deposited in the Cambridge Crystallographic Data Center with CCDC Numbers: CCDC-1490346 (1), CCDC-1490347 (2), and CCDC-1490348 (3), which contain supplementary crystallographic data for this paper. Other supplementary data associated with this article can be found in the online version. Supplementary information is available at www.ias.ac.in/chemsci.

\section{Acknowledgements}

This work was supported by the National Natural Science Foundation of China (Grant No. 21171123), and the Priority Academic Program Development of Jiangsu Higher Education Institutions (PAPD).

\section{References}

1. Wang K Y, Feng M L, Kong D N, Liang S J, Wu L and Huang X Y 2012 Layered indium chalcogenidoantimonates $\left[\mathrm{Me}_{2}, \mathrm{NH}_{2}\right]_{2} \mathrm{In}_{2} \mathrm{Sb}_{2} \mathrm{~S}_{7-\mathrm{x}} \mathrm{Se}_{\mathrm{x}}(\mathrm{x}=0,2.20,4.20$, 7) with tunable band gaps and photocatalytic properties CrystEngComm 1490

2. Haddadpour S, Mellullis M, Staesche H, Mariappan C R, Roling B, Clérac R and Dehnen S 2009 Inorganic frameworks from selenidotetrelate anions $\left[\mathrm{T}_{2} \mathrm{Se}_{6}\right]^{4-}(\mathrm{T}$ $=\mathrm{Ge}, \mathrm{Sn})$ : Synthesis, structures, and ionic conductivity of $\left[\mathrm{K}_{2}\left(\mathrm{H}_{2} \mathrm{O}\right)_{3}\right]\left[\mathrm{MnGe}_{4} \mathrm{Se}_{10}\right]$ and $\left(\mathrm{NMe}_{4}\right)_{2}\left[\mathrm{MSn}_{4} \mathrm{Se}_{1} \mathrm{O}\right]$ $(\mathrm{M}=\mathrm{Mn}, \mathrm{Fe})$ Inorg. Chem. 481689

3. Li J R and Huang X Y $2011\left[(\mathrm{Me})_{2} \mathrm{NH}_{2}\right]_{0.75}\left[\mathrm{Ag}_{1.25}\right.$ $\mathrm{SnSe}_{3}$ ]: A three-dimensionally microporous chalcogenide exhibiting framework flexibility upon ion-exchange Dalton Trans. 40387

4. Zhang Q C, Bu X H, Lin Z E, Biasini M, Beyemann W P and Feng P Y 2007 Metal-complex-decorated homochiral heterobimetallic telluride single-stranded helix Inorg. Chem. 467262

5. Zhao L D, Lo S H, He J Q, Li H, Biswas K, Androulakis J, Wu C I, Hogan T P, Chung D Y, Dravid V P and Kanatzidis M G 2011 High performance thermoelectrics from earth-abundant materials: Enhanced figure of merit in $\mathrm{PbS}$ by second phase nanostructures $J$. Am. Chem. Soc. 13320476

6. Xiong W W, Miao J W, Ye K Q, Wang Y, Liu B and Zhang Q C 2015 Threading chalcogenide layers with polymer chains Angew. Chem. Int. Ed. 54546

7. Sheldrick W S and Wachhold M 1998 Chalcogenidometalates of the heavier group 14 and 15 elements Coord. Chem. Rev. 176211

8. Li J, Chen Z, Wang R J and Proserpio D M 1999 Low temperature route towards new materials: Solvothermal synthesis of metal chalcogenides in ethylenediamine Coord. Chem. Rev. 190-192 707

9. Dehnen S and Melullis M 2007 A coordination chemistry approach towards ternary M/14/16 anions Coord. Chem. Rev. 2511259

10. Zhou J, Dai J, Bian G Q and Li C Y 2009 Solvothermal synthesis of group 13-15 chalcogenidometalates with chelating organic amines Coord. Chem. Rev. 2531221

11. Xiong W W and Zhang Q C 2015 Surfactants as promising media for the preparation of crystalline inorganic materials Angew. Chem. Int. Ed. 5411616

12. Eulenberger G 1982 Ternary thallium chalcogenides with $\mathrm{T}_{14} \mathrm{Ge}_{2} \mathrm{~S}_{6}$ structure Monatsh. Chem. 113859

13. Krebs V B and Muller H 1983 Selenogermanates from aqueous solution: Preparation and structure of $\mathrm{Na}_{4} \mathrm{Ge}_{2}$ $\mathrm{Se}_{6} \cdot 16 \mathrm{H}_{2} \mathrm{O}$ Z. Anorg. Allg. Chem. 49647

14. Eisenmann B and Hansa J 1993 Crystal structure of tetrapotassium hexaselenodigermanate, $\mathrm{K}_{4} \mathrm{Ge}_{2} \mathrm{Se}_{6} Z$. Kristallogr. 203301 
15. Melullis M, Brandmayer M K and Dehnen S 2006 Ortho-chalcogenotetrelate anions as chelating ligands: Syntheses and characterization of $\left[\mathrm{K}_{6}(\mathrm{MeOH})_{9}\right]\left[\mathrm{Sn}_{2}\right.$ $\left.\mathrm{Se}_{6}\right]\left[\mathrm{Cr}(\mathrm{en})_{2}\left(\mathrm{SnSe}_{4}\right)\right]_{2},\left[\mathrm{Na}\left(\mathrm{H}_{2} \mathrm{O}\right)_{4}\right]\left[\mathrm{Cr}(\mathrm{en})_{3}\right]_{2}\left[\mathrm{GeS}_{3} \mathrm{OH}\right]_{2}$ $\left[\mathrm{Cr}(\mathrm{en})_{2}\left(\mathrm{GeS}_{4}\right)\right]$, and $\left[\mathrm{Ba}\left(\mathrm{H}_{2} \mathrm{O}\right)_{10}\right]\left[\{\mathrm{Cr}(\mathrm{en})\}_{2}\left(\mathrm{GeSe}_{4}\right)_{2}\right]$ Z. Anorg. Allg. Chem. 63264

16. Morris C D, Malliakas C D and Kanatzidis M G 2011 Germanium selenophosphates: The incommensurately modulated ${ }^{1 / \infty}\left[\mathrm{Ge}_{4-\mathrm{x}} \mathrm{P}_{\mathrm{x}} \mathrm{Se}_{12}^{4-}\right]$ and the molecular $\left[\mathrm{Ge}_{2} \mathrm{P}_{2} \mathrm{Se}_{14}\right]^{6-}$ Inorg. Chem. 5010241

17. Chen Y K, Chen M C, Zhou L J, Chen L and Wu L M 2013 Syntheses, structures, and nonlinear optical properties of quaternary chalcogenides: $\mathrm{Pb}_{4} \mathrm{Ga}_{4} \mathrm{GeQ}_{12}(\mathrm{Q}=$ S, Se) Inorg. Chem. 528334

18. Ward M D, Pozzi E A, Duyne R P V and Ibers J A 2014 Syntheses, structures, and optical properties of the indium/germanium selenides $\mathrm{Cs}_{4} \mathrm{In}_{8} \mathrm{GeSe}_{16}, \mathrm{CsInSe}_{2}$, and $\mathrm{CsInGeSe}_{4}$ J. Solid State Chem. 212191

19. Park C W, Pell M A and Ibers J A 1996 Electrochemical synthesis of $\left[\mathrm{NEt}_{4}\right]_{2}[\mathrm{enH}]_{2}\left[\mathrm{Ge}_{2} \mathrm{Se}_{6}\right]$ and $\left[\mathrm{NEt}_{4}\right]_{4}\left[\mathrm{Sn}_{4} \mathrm{Se}_{10}\right]$ Inorg. Chem. 354555

20. Parise J B and Tan K 1996 Synthesis and structural characterization using synchrotron radiation of $\left[\left(\mathrm{C}_{6} \mathrm{H}_{13} \mathrm{~N}_{2}\right)_{2}\left(\mathrm{H}_{3} \mathrm{O}\right)\left(\mathrm{H}_{2} \mathrm{O}\right)\right]\left[\mathrm{AgGe}_{4} \mathrm{~S}_{10}\right]$ (dabco-AgGS-SB2): Knitting sulfide metal clusters to form frameworks Chem. Commun. 271687

21. Cahill C L and Parise J B 1997 Synthesis and structure of $\mathrm{MnGe}_{4} \mathrm{~S}_{10} \cdot\left(\mathrm{C}_{6} \mathrm{H}_{14} \mathrm{~N}_{2}\right) \cdot 3 \mathrm{H}_{2} \mathrm{O}$ : A novel sulfide framework analogous to zeolite Li-A(BW) Chem. Mater. 9 807

22. MacLachlan M J, Coombs N, Bedard R L, White S, Thompson L K and Ozin G A 1999 Mesostructured metal germanium sulfides J. Am. Chem. Soc. 12112005

23. Wachhold M, Rangan K K, Lei M, Thorpe M F, Billinge S J L, Petkov V, Heising J and Kanatzidis M G 2000 Mesostructured metal germanium sulfide and selenide materials based on the tetrahedral $\left[\mathrm{Ge}_{4} \mathrm{~S}_{10}\right]^{4-}$ and $\left[\mathrm{Ge}_{4} \mathrm{Se}_{10}\right]^{4-}$ units: Surfactant templated threedimensional disordered frameworks perforated with worm holes J. Solid State Chem. 15221

24. Trikalitis $P$ N, Rangan $\mathrm{K} K$ and Kanatzidis M G 2002 Platinum chalcogenido MCM-41 analogues. High hexagonal order in mesostructured semiconductors based on $\mathrm{Pt}^{2+}$ and $\left[\mathrm{Ge}_{4} \mathrm{Q}_{10}\right]^{4-}(\mathrm{Q}=\mathrm{S}, \mathrm{Se})$ and $\left[\mathrm{Sn}_{4} \mathrm{Se}_{10}\right]^{4-}$ adamantane clusters J. Am. Chem. Soc. 124 2604

25. Philippidis A and Trikalitis $\mathrm{P} \mathrm{N} 2009\left(\mathrm{H}_{2} \mathrm{NC}_{4} \mathrm{H}_{8} \mathrm{NCH}_{2}\right.$ $\left.\mathrm{CH}_{2} \mathrm{NH}_{2}\right)\left(\mathrm{HNCH}_{2} \mathrm{CH}_{2} \mathrm{NH}_{2}\right)_{3} \mathrm{Zn}_{2} \mathrm{Ge}_{2} \mathrm{Se}_{8}$ : A new, template one-dimensional ternary semiconductor stabilized by mixed organic cations Polyhedron 283193

26. Zhang B, Feng M L, Cui H H, Du C F, Qi X H, Shen N N and Huang X Y 2015 Syntheses, crystal structures, ionexchange, and photocatalytic properties of two aminedirected Ge-Sb-S compounds Inorg. Chem. 548474

27. Lin Y M, Massa W and Dehnen S 2012 Controlling the assembly of chalcogenide anions in ionic liquids: From binary $\mathrm{Ge} / \mathrm{Se}$ through ternary $\mathrm{Ge} / \mathrm{Sn} / \mathrm{Se}$ to binary $\mathrm{Sn} / \mathrm{Se}$ frameworks Chem. Eur. J. 1813427

28. Feng M L, Qi X H, Zhang B and Huang X Y 2014 $\left[(\mathrm{Me})_{2} \mathrm{NH}_{2}\right]\left[\mathrm{BiGeS}_{4}\right]$ : The first organically directed bismuth thiogermanate with $\mathrm{Rb}^{+}$ion exchange property Dalton Trans. 438184

29. Han X H, Wang Z Q, Xu J, Liu D and Wang C 2015 A crown-like heterometallic unit as the building block for a 3D In-Ge-S framework Dalton Trans. 4419768

30. Jia D X, Dai J, Zhu Q Y, Cao L H and Lin H H 2005 Solvothermal synthesis of three new dimeric thiogermanates $(\mathrm{enH})_{4} \mathrm{Ge}_{2} \mathrm{~S}_{6}, \quad\left[\mathrm{Mn}(\mathrm{en})_{3}\right]_{2} \mathrm{Ge}_{2} \mathrm{~S}_{6}$ and $\left[\mathrm{Ni}(\mathrm{en})_{3}\right]_{2} \mathrm{Ge}_{2} \mathrm{~S}_{6}$ from germanium dioxide and sulfur powder J. Solid State Chem. 178874

31. Jia D X, Zhu A M, Zhang Y and Deng J 2007 New selenidogermanates with transition-metal complexes as counterions: Solvothermal synthesis, crystal structures, and properties of $\left[\mathrm{Mn}(\mathrm{en})_{3}\right]_{2} \mathrm{Ge}_{2} \mathrm{Se}_{6}$ and $\left[\mathrm{Fe}(\mathrm{dien})_{2}\right]_{2}$ $\mathrm{Ge}_{2} \mathrm{Se}_{6}$ Monatsh. Chem. 138191

32. Lichte J, Näther C and Bensch W 2014 Polymorphism and tautomerism in $\left[\operatorname{dienH} H_{2},\right]\left[\mathrm{Co}(\operatorname{dien})_{2}\right]\left[\mathrm{Ge}_{2} \mathrm{~S}_{6}\right]$ leading to different hydrogen bonded networks CrystEngComm 165551

33. Zhou J, An L T, Liu X, Huang L J and Huang X J 2011 Solvothermal synthesis and characterization of two 2-D layered germanium thioantimonates with transitionmetal complexes Dalton Trans. 4011419

34. Zhou J, Liu X, Liang GM, Liang WJ, Hu FL and Zhu LG 2013 [Ni(dien $\left.)_{2}\right]_{3}\left[\mathrm{Ge}_{3} \mathrm{Sb}_{8} \mathrm{~S}_{21}\right] \cdot 0.5 \mathrm{H}_{2} \mathrm{O}$ : A new 2-D layered thiogermanate-thioantimonate with metal complexes as template ions Inorg. Chem. Comm. 2792

35. Liu G N, Lin J D, Xu Z N, Liu Z F, Guo G C and Huang J S 2011 Spontaneous resolution of a new thiogermanate containing chiral binuclear nickel(II) complexes with achiral triethylenetetramine ligands: A unique watermediated supramolecular hybrid helix Cryst. Growth. Des. 113318

36. Zhang Q C, Armatas G and Kanatzidis M G 2009 Activation of tellurium with zintl ions: ${ }^{1} / \infty\left\{\left[\mathrm{Ge}_{5} \mathrm{Te}_{10}\right]^{4-}\right\}$, an inorganic polymer with germanium in three different oxidation states Inorg. Chem. 488665

37. Almsick T V, Loose A and Sheldrick W S 2005 Solvothermal synthesis and structure of the $\left[\mathrm{Ge}_{2} \mathrm{Se}_{7}\right]^{4-}$ Anion in $\left(\mathrm{enH}_{2}\right)\left[\left\{\mathrm{Mn}(\mathrm{en})_{2}(\mathrm{enH})\right\}_{2}(\mu\right.$-en $\left.)\right]\left(\mathrm{Ge}_{2} \mathrm{Se}_{7}\right)_{2}$ and $\left[\mathrm{Mn}(\mathrm{dien})_{2}\right]_{2} \mathrm{Ge}_{2} \mathrm{Se}_{7}$ Z. Anorg. Allg. Chem. 63121

38. Zhang G D, Li P Z, Ding J F, Liu Y, Xiong W W, Nie L N, Wu T, Zhao Y L, Tok A I Y and Zhang Q C 2014 Surfactant-thermal syntheses, structures, and magnetic properties of $\mathrm{Mn}-\mathrm{Ge}-$ sulfides/selenides Inorg. Chem. 5310248

39. Tang $\mathrm{W} \mathrm{W}$, Liang $\mathrm{J} \mathrm{J}$, Jiang $\mathrm{W} \mathrm{Q}, \mathrm{Wu} \mathrm{B}$, Zhang Y and Jia D X 2011 The first examples of selenidogermanate salts with lanthanide complex counter cations: Solvothermal syntheses and characterizations of $\left[\left\{\mathrm{Ln}(\mathrm{en})_{3}\right\}_{2}(\mu-\mathrm{OH})_{2}\right] \mathrm{Ge}_{2} \mathrm{Se}_{6}(\mathrm{Ln}=E u, H o)$ and $\left[\left\{\mathrm{Ho}(\operatorname{dien})_{2}\right\}_{2}(\mu-\mathrm{OH})_{2}\right] \mathrm{Ge}_{2} \mathrm{Se}_{6}$ Z. Anorg. Allg. Chem. 6371539

40. Chen R H, Tang W W, Liang J J, Jiang W Q, Zhang Y and Jia D X 2012 The first $\mu-\mathrm{Ge}_{2} \mathrm{Se}_{8}$ ligand to lanthanide(III) centers: Solvothermal syntheses and characterizations of lanthanide selenidogermanate complexes with a pentadentate polyamine as a co-ligand Dalton Trans. 4112439

41. Zhou J, Li R, Ling X, Chen R, Hu F and Zeng Y 2013 The first examples of thiogermanate anion 
$\left[\mathrm{GeS}_{3}(\mathrm{SH})\right]^{3-}$ as a bridging ligand to a lanthanide complex Dalton Trans. 421961

42. Kromm A and Sheldrick W S 2008 Synthesis and structures of dimanganese(II) complexes with spirotricyclic $\left[\mathrm{Mn}\left(\mu-\mathrm{Ge}_{2} \mathrm{Se}_{7}\right) \mathrm{Mn}\right]$ and $\left.\left[\mathrm{Mn}-\mathrm{Sn}_{2} \mathrm{Se}_{6}\right) \mathrm{Mn}\right]$ cores Z. Anorg. Allg. Chem. 6341005

43. Liu G N, Guo G C, Wang M S, Cai L Z and Huang J S 2010 Five dimeric thiogermanates with transition metal complexes of multidentate chelating amines: Syntheses, structures, magnetism and photoluminescence $\mathrm{J}$. Mol. Struct. 983104

44. Liang J J, Zhao J, Tang W W, Zhang Y and Jia D X 2011 Ethylene polyamine influence on the transition metal thiogermanates: Solvothermal syntheses and characterizations of $\left[\mathrm{Ni}(\text { trien })_{2}\right]_{2} \mathrm{Ge}_{4} \mathrm{~S}_{10}$ and $\left[\{\mathrm{Ni}(\text { tepa })\}_{2}(\mu\right.$ $\left.\mathrm{Ge}_{2} \mathrm{~S}_{6}\right)$ ] Inorg. Chem. Comm. 141023
45. Chen J F, Jin Q Y, Pan Y L, Zhang Y and Jia D X 2010 Solvothermal syntheses and characterization of new transition metal chalcogenidogermanates $\left[\{\mathrm{Co}(\text { tepa })\}_{2}\right.$ $\left.\left(\mu-\mathrm{Ge}_{2} \mathrm{~S}_{6}\right)\right]$ and $\left[\{\mathrm{M}(\text { tepa })\}_{2}\left(\mu-\mathrm{Ge}_{2} \mathrm{Se}_{6}\right)\right](M=\mathrm{Mn}, \mathrm{Fe})$ (tepa $=$ tetraethylenepentamine) Z. Anorg. Allg. Chem. 636230

46. Wendlandt W W and Hecht H G 1966 In Reflectance Spectroscopy (New York: Interscience Publishers)

47. Sheldrick G M 1997 In SHELXS-97 Program for structure solution (Germany: Universität of Göttingen)

48. Sheldrick G M 1997 In SHELXL-97 Program for structure refinement (Germany: Universität of Göttingen)

49. Mitzi D B 2005 Synthesis, structure, and thermal properties of soluble hydrazinium germanium(IV) and tin(IV) selenide salts Inorg. Chem. 443755 